\title{
A EXPERIÊNCIA DA FAMília NO PROCESSO DE SOCIALIZAÇAO DA CRIANÇA E DO ADOLESCENTE COM DEFICIÊNCIA VISUAL
}

\section{Pôster}

Autores deste trabalho:

\author{
Mayara Caroline Barbieri: Universidade Federal de São Carlos \\ Gabriela Van Der Zwaan Broekman: Universidade Federal de São Carlos \\ Beatriz Castanheira Facio: Universidade Federal de São Carlos \\ Monika Wernet: Universidade Federal de São Carlos \\ Regina Aparecida Garcia de Lima: Universidade de São Paulo- Escola de Enfermagem \\ de Ribeirão Preto
}

Giselle Dupas: Universidade Federal de São Carlos

Área do Trabalho: Enfermagem pediátrica

Número de inscrição: 5532

Data da submissão:30/08/2016 às 07:35

\section{Justificativa}

A Política Nacional de Saúde da Pessoa Portadora de Deficiência é voltada para a reabilitação da pessoa, de modo a auxiliar sua inclusão plena em todas as esferas da vida social A deficiência visual (DV) pode ocasionar inúmeras dificuldades e modificações na rotina da família e do membro, sendo uma delas o processo de socialização.

\section{Objetivo(s)}

Compreender a experiência de famílias no processo de socialização vivenciado por crianças e adolescentes com deficiência visual.

\section{Método(s)}

Investigação descritiva, qualitativa que utilizou o Interacionismo Simbólico (IS) como referencial teórico e a Análise de Narrativa como método. Os participantes foram crianças e adolescentes com deficiência visual e seus familiares, considerando o conceito de família proposto por Wright e Leahey. Para a coleta de dados utilizamos o genograma, ecomapa e entrevista semiestruturada, em um único encontro, em local escolhido pela família, gravada com 18 famílias, totalizando 61 participantes. A coleta de dados ocorreu 
no período de novembro de 2014 à julho de 2015. A pesquisa foi aprovada pelo Comitê de Ética em Pesquisa com Seres Humanos, número: 748751.

\section{Resultado(s)}

A família por ser o primeiro espaço de interações, se mostrou essencial no processo de socialização da criança e do adolescente com DV, agindo para valorizar e buscar outras estratégias para que o membro pudesse desvendar o mundo para além do núcleo familiar. A inserção na escola, em ambientes religiosos e culturais é estimulado pela família, apesar desses processos de socialização serem repletos de desafios, como o preconceito. A família, por vezes, tenta superproteger a criança e adolescente do enfrentamento dessas vivências, porém reflete e busca se conter nesta intervenção, por reconhecer os benefícios da interação.

\section{Conclusão(ões)}

A inclusão social da criança é almejada pela família. Apesar dos desafios, os membros reconhecem essa estratégia como primordial para o empoderamento de seus membros. Os profissionais envolvidos com a assistência à criança e ao adolescente com deficiência visual devem promover ações em grupo com alunos, comunidade e familiares para abrir espaço ao diálogo e discussões sobre o respeito as diferenças, para promover a integração e socialização das pessoas com DV. 